\title{
Oocyst Excretion in Dogs Fed Mouse Brains Containing Tissue Cysts of a Cloned Line of Neospora Caninum
}

\author{
Author(s): David S. Lindsay, Dianne M. Ritter, David Brake \\ Source: Journal of Parasitology, 87(4):909-911. 2001. \\ Published By: American Society of Parasitologists \\ DOI: http://dx.doi.org/10.1645/0022-3395(2001)087[0909:OEIDFM]2.0.CO;2 \\ URL: http://www.bioone.org/doi/full/10.1645/0022-3395\%282001\%29087\%5B0909\%3AOEIDFM \\ $\% 5 \mathrm{D} 2.0 . \mathrm{CO} \% 3 \mathrm{~B} 2$
}

BioOne (www.bioone.org) is a nonprofit, online aggregation of core research in the biological, ecological, and environmental sciences. BioOne provides a sustainable online platform for over 170 journals and books published by nonprofit societies, associations, museums, institutions, and presses.

Your use of this PDF, the BioOne Web site, and all posted and associated content indicates your acceptance of BioOne's Terms of Use, available at www.bioone.org/page/terms_of_use.

Usage of BioOne content is strictly limited to personal, educational, and non-commercial use. Commercial inquiries or rights and permissions requests should be directed to the individual publisher as copyright holder. 
malmbergi, which shifted from $O$. niloticus to $C$. callolepis in Santa Anita Lagoon. The prevalence and abundance of C. sclerosus and $C$. tilapiae were higher in CINVESTAV-Mérida than in Lake Catemaco. This is probably a consequence of direct parasite transmission in a crowded environment. The presence of these monogeneans in the CINVESTAV aquaculture facilities highlights the increased mortality risk these parasites pose for cultured fish, as has been recorded for cichlid fish in Florida (Noga and Flowers, 1995).

We are grateful to D. C. Kritsky of Idaho State University at Pocatello, T. Scholz of the Parasitology Institute of the Sciences Academy of the Czech Republic, and L. Aguirre-Macedo of Centre of Investigation and Advanced Studies-Mérida for revision of an early version of this manuscript. Our thanks to Mark Torchin for helping us to improve the English of the manuscript and G. Cabañas-Carranza, C. Vivas-Rodríguez, and G. Arjona-Torres for technical assistance. This study was supported in part by project M-135 of the CONABIO, México, the JIRA-CINVESTAV (1997) Floating Cages Project (Estudio Experimental de la Transmisión de los Macroparásitos de Peces Nativos a Cultivados en Jaulas Flotantes), and the grant, titled The Role of Parasites in the Invasion Success of Introduced Fish Species of México and the United States, supported by UC-MEXUS-CONACyT. We are grateful to CONACyT Mexico for awarding a studentship to M. I. J. G. This paper is partly based on the Ph.D. thesis of M. I. J. G.

\section{LITERATURE CITED}

Arredondo-FigueroA, J. L. 1983. Especies animales acuáticas de importancia nutricional introducidas en México. Biótica 8: 175-199.

BAUER, O. N. 1991. Spread of parasites and diseases of aquatic organisms by acclimatization: A short review. Journal of Fish Biology 39: 679-686.
ERGENS, R. 1969. The suitability of ammonium picrate-glycerin in preparing slides of lower Monogenoidea. Folia Parasitologica 16: 320.

Jiménez-García, M. I. 1996. Comunidades de Parásitos de los Peces del Lago de Catemaco, Veracruz, México. Tesis Maestría en Ciencias. Universidad Nacional Autónoma de México, México, D.F., $110 \mathrm{p}$.

Kritsky, D. C., AND V. E. Thatcher. 1974. Monogenetic trematodes (Monopisthocotylea: Dactylogyridae) from freshwater fishes of Colombia, South America. Journal of Helminthology 48: 59-66.

, V. M. Vidal-MartíneZ, and R. RodrígueZ-CanUl. 1994. Neotropical Monogenoidea. 19. Dactylogyridae of Cichlids (Perciformes) from the Yucatán Peninsula, with descriptions of three new species of Sciadicleithrum Kritsky, Thatcher, and Boeger, 1989. Journal of the Helminthological Society of Washington 61: 26-33.

LAZARO-ChÁveZ, E. 1985. Análisis patológico de las alteraciones producidas por ectoparásitos en reproductores de Tilapia Sarotherodon hornarum (Trewavas) y Oreochromis mossambicus (Peters). Revista Latinoamericana de Acuicultura 25: 24-30.

Margolis, L., G. W. Esch, J. C. Holmes, A. M. Kuris, and G. M. SCHAD. 1982. The use of ecological terms in parasitology. Journal of Parasitology 68: 131-133.

NogA, E. J., AND J. R. Flowers. 1995. Invasion of Tilapia mossambica (Cichlidae) viscera by the monogenean Enterogyrus cichlidarum. Journal of Parasitology 81: 815-817.

Prieto, A., E. FAJER, AND M. VinJoy. 1985. Cichlidogyrus sclerosus (Monogenea: Ancyrocephalinidae) in Tilapia hornorum $\times$ Tilapia mossambica (perca dorada) en cultivo intensivo. Revista de Salud Animal 7: 291-295.

Pullin, R. S. V. 1991. Cichlids in aquaculure. In Cichlid fishes. Behaviour, ecology and evolution, M. H. A. Keenleyside (ed.). Chapman and Hall, London, U.K., p. 280-300.

Salgado-Maldonado, G., R. Pineda-López, V. M. Vidal-Martínez, AND C. R. KENNEDY. 1997. A checklist of metazoan parasites of cichlid fish from México. Journal of the Helminthological Society of Washington 64: 195-207.

Zambrano, L., AND C. Macías-García. 1999. Impact of introduced fish for aquaculture in Mexican freshwater systems. In Nonindigenous freshwater organisms. Vectors, biology, and impacts, R. Claudi and J. H. Leach (eds.). Lewis Publishing, Boca Raton, Florida, p. 113124.

\section{Oocyst Excretion in Dogs Fed Mouse Brains Containing Tissue Cysts of a Cloned Line of Neospora Caninum}

David S. Lindsay, Dianne M. Ritter ${ }^{\star}$, and David Brake*, Center for Molecular Medicine and Infectious Diseases, Department of Biomedical Sciences and Pathobiology, Virginia-Maryland Regional College of Veterinary Medicine, Virginia Tech, 1410 Prices Fork Road, Blacksburg, Virginia 24061-0342; *Pfizer Global Research and Development, Building 288, Eastern Point Road, Groton, Connecticut 06340.

ABSTRACT: Neospora caninum is an apicomplexan parasite that causes neonatal neuromuscular disease in dogs and abortions in cattle. Bovine neosporosis is a major production problem worldwide. The parasite is transmitted to cattle via oocysts excreted by dogs or by transplacental transmission. Dogs are the only proven definitive host for $N$. caninum. One of 3 dogs fed mouse brains containing tissue cysts of a wild-type $N$. caninum strain CK0160SC3B (CKO) excreted oocysts in its feces. Two of 3 dogs fed mouse brains containing tissue cysts from a cloned line of the CKO strain excreted $N$. caninum oocysts in their feces. The results indicate that a single $N$. caninum tachyzoite contains all the genetic information needed to produce the asexual and sexual cycles in the canine intestine.

Neospora caninum is an apicomplexan parasite that causes neonatal neuromuscular disease in dogs and abortions in cattle (reviewed by Dubey and Lindsay, 1996). Dogs are a definitive host of N. caninum (McAllister et al., 1998; Lindsay, Dubey, and Duncan, 1999; Lindsay, Upton, and Dubey, 1999). They are essential in the initial transmission of this parasite to cattle, and large abortion storms seen on farms are probably due to feed or water contaminated with $N$. caninum oocysts (i.e., postnatal transmission; McAllister et al., 1996; Thurmond et al., 1997; Schares et al., 1999). Before dogs were shown to be a definitive host, they were associated with neosporosis on farms in epidemiological studies (Pare et al., 1998), and this positive association has been verified by recent studies (Mainar-Jaime et al., 1999; Ould-Amrouche et al., 1999; Wouda et al., 1999). Neosporosis is an economically important cause of abortion 
worldwide in dairy and beef cattle (Dubey and Lindsay, 1996); however, little is known about the life cycle of this parasite in the canine definitive host.

The present study was done to determine if dogs would excrete oocysts after ingesting tissue cysts of a wild type of $N$. caninum isolated from beef cattle and to determine if dogs fed tissue cysts resulting from infections with cloned tachyzoites would excrete oocysts. If dogs fed tissue cysts resulting from infections with cloned tachyzoites excreted oocysts, this would indicate that a single tachyzoite contained all the genetic information needed to produce the male and female sexual cycles in the canine definitive host.

Tachyzoites of the CK0160SC3B (CKO) strain of N. caninum isolated from an aborted bovine fetus were used in the present study. The CKO strain was cloned twice by limiting dilution and the resulting clone of $N$. caninum called the PB-1-2C clone. Eighty CD-1 mice were injected intramuscularly with $4 \mathrm{mg}$ methylprednisolone acetate (MPA) on days -7 and 0 postinoculation (PI) of $2 \times 10^{5}$ tachyzoites. Forty mice received tachyzoites of the CKO strain (14th passage in cell culture) and 40 received tachyzoites of the $\mathrm{PB}-1-2 \mathrm{C}$ line (7th passage in cell culture).

Mice had been infected with the CKO strain for 58 days (experiment 1) or 92 days (experiment 2) before being fed to dogs. Mice had been infected with the PB-1-2C strain for 72 days (experiment 1) or 86 days (experiment 2) before being fed to dogs. Brains from a mouse in each group were examined for $N$. caninum tissue cysts by squash preparation and light microscopy. Tissue cysts were observed in squash preparations in mice from all groups. Dogs were fed mouse brains that had been removed from mice for less than $30 \mathrm{~min}$.

Six mixed-breed dogs about 12 -wk old were used. Two experiments were conducted. Dogs in both experiments received $100 \mathrm{mg}$ MPA intramuscularly on days -7 and 0 PI. In experiment 1 , dogs 8 and 9 were each fed 12 mouse brains containing the CKO strain, and dogs 12 and 13 were each fed 12 mouse brains containing the PB-1-2C line. In experiment $2, \operatorname{dog} 16$ was fed 12 mouse brains, each containing the CKO strain, and dog 17 was fed 15 mouse brains, each containing the PB-1-2C line. Dogs were infected separately by placing the infected mouse brains in the dogs' feed bowls. This was done in the morning before the dogs were fed, but they were not fasted overnight. Each dog was watched to ensure it has ingested all the brains present. The dogs were then given their morning ration. Dogs were re-examined at $30 \mathrm{~min}$ and $1 \mathrm{hr}$ to determine if they had vomited the inoculum.

Feces of each dog were examined for $N$. caninum oocyst excretion on days 4-15 PI by flotation in Sheather's sugar solution (Ernst and Benz, 1981; Table I). Feces containing unsporulated oocysts were collected, mixed in $2 \%(\mathrm{v} / \mathrm{v})$ sulfuric acid solution ( 1 part feces to 9 parts sulfuric acid solution), strained with a tea strainer, and placed in 1-L erlenmeyer flasks to a depth of about $40 \mathrm{~cm}$, and the suspension was mixed on a rotating mixer for $48-72 \mathrm{hr}$. Sporulated oocysts were purified by flotation in Sheather's sugar solution. Briefly, the oocyst sulfuric acid solution was concentrated in 50-ml tubes by centrifugation for $10 \mathrm{~min}$ at $1,500 \mathrm{rpm}$. The pellet was mixed with $40 \mathrm{ml}$ Sheather's sugar solution and centrifuged again for 10 min at 1,500 rpm. The top layer of the suspension containing the sporulated oocysts was collected. mixed in tap water, and
TABLE I. Direct agglutination titers (expressed as reciprocals) of dogs fed mouse brains containing the CK0160SC3B (dogs 8, 9, 16) or PB$1-2 \mathrm{C}$ (dogs 12,13, and 17) strain of Neospora caninum.

\begin{tabular}{|c|c|c|c|c|c|c|}
\hline \multirow[b]{2}{*}{ Day PI* } & \multicolumn{3}{|c|}{ Dogs fed CK0160SC3B strain } & \multicolumn{3}{|c|}{ Dogs fed PB-1-2C strain } \\
\hline & 8 & 9 & $16 \dagger$ & 12 & $13 \dagger$ & $17 \dagger$ \\
\hline-22 & $\mathrm{Nd} \ddagger$ & $\mathrm{Nd}$ & - & - & - & - \\
\hline-14 & - & - & $\mathrm{Nd}$ & - & - & $\mathrm{Nd}$ \\
\hline-7 & - & - & $\mathrm{Nd}$ & - & - & $\mathrm{Nd}$ \\
\hline 0 & - & - & - & - & - & - \\
\hline 6 & - & - & $\mathrm{Nd}$ & $\mathrm{Nd}$ & $\mathrm{Nd}$ & $\mathrm{Nd}$ \\
\hline 7 & $\mathrm{Nd}$ & $\mathrm{Nd}$ & - & 100 & 100 & - \\
\hline 11 & - & - & $\mathrm{Nd}$ & $\mathrm{Nd}$ & $\mathrm{Nd}$ & $\mathrm{Nd}$ \\
\hline 14 & $\mathrm{Nd}$ & $\mathrm{Nd}$ & - & 200 & 50 & - \\
\hline 15 & - & 25 & $\mathrm{Nd}$ & $\mathrm{Nd}$ & $\mathrm{Nd}$ & $\mathrm{Nd}$ \\
\hline 20 & - & 25 & $\mathrm{Nd}$ & $\mathrm{Nd}$ & $\mathrm{Nd}$ & $\mathrm{Nd}$ \\
\hline 21 & $\mathrm{Nd}$ & $\mathrm{Nd}$ & 50 & $\mathrm{Nd}$ & $\mathrm{Nd}$ & - \\
\hline 28 & 800 & 100 & 100 & $\mathrm{Nd}$ & $\mathrm{Nd}$ & - \\
\hline 36 & 800 & 100 & 800 & $\mathrm{Nd}$ & $\mathrm{Nd}$ & - \\
\hline
\end{tabular}

* Day postinoculation (PI) sera sample collected.

$\dagger$ Dog excreted oocysts.

$+\mathrm{Nd}$, no test conducted that day PI.

repelleted by centrifugation for $10 \mathrm{~min}$. The pellet containing concentrated sporulated oocysts was stored at $4 \mathrm{C}$ in $2 \%$ sulfuric acid solution until used.

Concentrated fecal samples were treated with $50 \%(\mathrm{v} / \mathrm{v})$ commercial bleach for $10 \mathrm{~min}$ to digest contaminating fecal material still present. The chlorine from the bleach was removed by repeated centrifugation in Hanks' balanced salt solution. The estimated numbers of total oocysts present from each dog that was visibly positive was determined by counting the numbers of oocysts present in the final pool of bleach-treated oocysts from that dog using a hemocytometer.

Blood samples were collected from each dog on days -7 and 0 before feeding oocysts and on days 14 (dogs 12 and 13) or 36 (dogs 8, 9, 16, and 17) after feeding infected mouse brains. The anti- $N$. caninum antibody titers were determined by the modified direct agglutination test (NAT) (Packham et al., 1998) on serum. Sera were examined at dilutions of 1:25 and endpoint titrated.

Three female gerbils were used to test infectivity of PB-12C strain oocysts as described by Dubey and Lindsay (2000). Two were fed 6,000 oocysts each, and 1 was fed 20,0000 oocysts of the PB-1-2C strain. The 2 gerbils fed 6,000 oocysts were both killed 93 days PI. Blood was collected from the retroorbital plexus and used for antibody determination in the NAT. Their brains were removed and $1 / 2$ was fixed in $10 \%$ neutral buffered formalin and processed for histological examination. The remaining $1 / 2$ was homogenized and inoculated onto cell cultures. The gerbil fed 20,000 oocysts died 25 days PI, and its brain was removed and processed for histology.

Six female $\gamma$-INF gene knockout mice were used to test the infectivity of a second batch of PB-1-2C oocysts. Three mice were subcutaneously inoculated with 5,000 oocysts each and 3 mice were fed 5,000 oocysts each. They were killed 30 days PI, and sera were collected for NAT testing. Their brains were removed and processed for histological examination.

None of the dogs fed infected mouse brains developed diarrhea or any other clinical sign of intestinal disease. All dogs 
ate the inoculum within $2 \mathrm{~min}$. Most consumed the brains within $30 \mathrm{sec}$. None of the dogs vomited the inoculum.

One of the 3 dogs (dog 16) fed the CKO strain excreted oocysts in its feces for a single day on day 13 PI. Two of 3 dogs (dogs 13 and 17) fed the PB-1-2C strain excreted N. caninum oocysts. Dog 13 excreted oocysts on days 7, 8, 9, 10, 11, 12, 13, and 14 PI. Dog 17 excreted oocysts on days 8, 9, 10, 12,13 , and 15 PI. Oocyst production was minimal in dogs that excreted oocysts. Total oocysts of the PB-1-2C strain collected and purified from dogs 13 and 17 were approximately 810,000 and 161,000 , respectively. No oocysts of the CKO strain were observed in the processed feces of dog 16 .

None of the $6 \mathrm{dogs}$ had antibodies to $N$. caninum prior to being fed mouse brains (Table I). Five of 6 dogs seroconverted to $N$. caninum during the study. Dogs 8 and 9 fed the CKO strain had titers of 1:800 and 1:100, respectively, on day $36 \mathrm{PI}$ despite not excreting visible $N$. caninum oocysts in their feces, whereas dog 16 fed the CKO strain did excrete oocysts and had a titer of 1:800 on day 36 PI. Dog 12 fed the PB-1-2C strain did not excrete oocysts but had a titer of 1:200 on day 14, and dog 13 fed PB-1-2C strain did excrete oocysts and had a titer of 1:50 on day 14 PI. Dog 17 fed the PB-1-2C strain excreted oocysts but did not seroconvert by day $36 \mathrm{PI}$.

The gerbil fed 20,000 PB-1-2C oocysts of $N$. caninum collected from dog 13 died (apparently of a seizure) 25 days PI. No serum was obtained. Minimal lesions were present in its brain, and they consisted of focal areas of gliosis. No tissue cysts were seen in this gerbil. Neither of the 2 gerbils fed 6,000 oocysts of the PB-1-2C strain of $N$. caninum collected from dog 13 died. Both gerbils had agglutinating titers that were $\geq 1$ : 800 in their sera 93 days PI. Neospora caninum was not isolated in cell cultures from the brain of either gerbil during the 53 days the cultures were kept for examination. No lesions were present in the brains of these 2 gerbils. None of the $3 \gamma$-INF gene knockout mice subcutaneously inoculated with PB-1-2C oocysts from dog 17 or the $3 \gamma$-INF gene knockout mice fed oocysts from dog 17 died. No antibodies to $N$. caninum were present in a 1:25 dilution of sera from any of these $6 \gamma$-INF gene knockout mice. No lesions were present in the brains of these mice.

None of the dogs fed $N$. caninum-infected mouse brains developed clinical signs of disease in the present study. This is consistent with previous reports (McAllister et al., 1998; Lindsay et al., 1999). It is also interesting to note that not all dogs seroconverted and that dog 17 excreted oocysts and did not seroconvert by day 36 PI. The low numbers of oocysts excreted by dogs may indicate that they are not the best definitive host for this parasite. It is possible that some other carnivore is the true definitive host in nature.

The oocysts of the PB-1-2C strain collected from dog 13 were infectious for gerbils as measured by lesions in the gerbil fed 20,000 oocysts and in the titers of $\geq 1: 800$ in the 2 fed 6,000 oocysts. Oocysts of the PB-1-2C strain do not appear to be pathogenic for gerbils as the NC-Liverpool strain. The NCLiverpool strain of $N$. caninum will cause fatal infections in gerbils fed as few as 1,000 oocysts (Dubey and Lindsay, 2000). The oocysts of the PB-1-2C strain collected from dog 17 were not infectious for $\gamma$-INF gene knockout mice. Oocysts of the NC-beef strain of $N$. caninum were also not very infectious for
$\gamma$-INF gene knockout mice because only 1 of 8 became infected (Lindsay et al., 1999).

The finding that the cloned line, PB-1-2C, could induce oocyst production in dogs indicates that all the genetic material needed is present in a single tachyzoite. Our results are similar to those of Pfefferkorn et al. (1977), who demonstrated that a cloned strain of Toxoplasma gondii could induce oocyst excretion in cats.

We thank Brent Bowden and Kay Carlson, Virginia-Maryland Regional College of Veterinary Medicine, Virginia Tech, Blacksburg, Virginia, for technical assistance.

\section{LITERATURE CITED}

ERnst, J. V., AND G. W. BENZ. 1981. Coccidiosis. In Diseases of cattle in the tropics, M. Ristic and I. McIntyre (eds.). Martinus Nijhoff, The Hague, The Netherlands, p. 337-392.

Dubey, J. P., AND D. S. LindSAY. 1996. A review of Neospora caninum and neosporosis. Veterinary Parasitology 67: 1-59.

, AND - 2000. High susceptibility of gerbils to oral infection with Neospora caninum oocysts. Parasitology Research 86: $165-168$

Lindsay, D. S., J. P. Dubey, And R. B. Duncan. 1999. Confirmation that the dog is a definitive host for Neospora caninum. Veterinary Parasitology 82: 327-333.

- S. J. Upton, AND J. P. DuBey. 1999. A structural study of the Neospora caninum oocyst. International Journal for Parasitology 29: $1521-1523$.

Mainar-Jaime, R. C., M. C. Thurmond, B. Berzal-Herranz, and S. K. Hietala. 1999. Seroprevalence of Neospora caninum and abortion in dairy cows in northern Spain. Veterinary Record 145: $72-$ 75.

McAllister, M. M., E. M. Huffman, S. K. Hietala, P. A. Conrad, M. L. Anderson, And M. D. Salman. 1996. Evidence suggesting a point source exposure in an outbreak of bovine abortion due to neosporosis. Journal of Veterinary Diagnostic Investigation 8: $355-$ 357.

— J. P. Dubey, D. S. Lindsay, W. R. Jolley, A. N. Wills, And A. M. MCGuIRE. 1998. Dogs are definitive hosts of Neospora caninum. International Journal for Parasitology 28: 1473-1478.

Ould-Amrouche, A., F. Klein, C. Osdoit, O. H. Mohammed, A. TourAtier, M. SanAA, AND J. P. Mialot. 1999. Estimation of Neospora caninum seroprevalence in dairy cattle from Normandy, France. Veterinary Research 30: 531-538.

Packham, A. E., K. W. Sverlow, P. A. Conrad, E. F. Loomis, J. D. Rowe, M. L. Anderson, A. E. Marsh, C. Cray, and B. C. Barr. 1998. A modified agglutination test for Neospora caninum: Development, optimization, and comparison to the indirect fluorescentantibody test and enzyme-linked immunosorbent assay. Clinical and Diagnostic Laboratory Immunology 5: 467-473.

Pare, J., G. Fecteau, M. Fortin, and G. Marsolais. 1998. Seroepidemiologic study of Neospora caninum in dairy herds. Journal of the American Veterinary Medical Association 213: 1595-1598.

Pfefferkorn, E. R., L. C. Pfefferkorn, and E. D. Colby. 1977. Development of gametes and oocysts in cats fed cysts derived from cloned trophozoites of Toxoplasma gondii. Journal of Parasitology 63: $158-159$.

Schares, G., M. Rauser, K. Zimmer, M. Peters, R. Wurm, J. P. Dubey, D. C. de Graaf, R. Edelhofer, C. Mertens, G. Hess, and F. J. ConRATHS. 1999. Serological differences in Neospora caninum-associated epidemic and endemic abortions. Journal of Parasitology 85: 688-694.

Thurmond, M. C., S. K. Hietala, and P. C. Blanchard. 1997. Herdbased diagnosis of Neospora caninum-induced endemic and epidemic abortion in cows and evidence for congenital and postnatal transmission. Journal of Veterinary Diagnostic Investigation 9: 4449.

Wouda, W., T. Dijkstra, A. M. H. Kramer, C. van MaAnen, and J. M. A. BRINKHOF. 1999. Seroepidemiological evidence for a relationship between Neospora caninum infections in dogs and cattle. International Journal for Parasitology 29: 1677-1682. 